\title{
THE EFFECT OF SOCIAL AND LEGAL ENVIRONMENTS TOWARD WELFARE WITH ECONOMIC EXPENDITURES AS INTERVENING VARIABLES
}

\author{
Agus Tripriyono \\ Doctor of Area Planning \\ Universitas Sumatera Utara \\ Medan, Indonesia \\ agustripriyono@usu.ac.id \\ Sirojuzilam \\ Department of Economic Development, \\ Universitas Sumatera Utara \\ Medan, Indonesia \\ sirojuzilam@usu.ac.id
}

\author{
Erlina \\ Department of Accounting \\ Universitas Sumatera Utara \\ Medan, Indonesia \\ erlina@usu.ac.id \\ Agus Purwoko \\ Department of Forestry \\ Universitas Sumatera Utara \\ Medan, Indonesia \\ aguspurwoko@usu.ac.id
}

\begin{abstract}
This study aims to examine the influence of the social environment and the legal environment on the welfare of society with economic expenditure as a mediator. The independent variables of this research are the social environment and the legal environment and its dependent variables are community welfare and economic expenditure as the mediating variable. This type of research is descriptive quantitative. The type of data used is the primary data using ordinal scale. The population is 304 respondents with selected sample type with Purposive Sampling as much as $\mathbf{2 0 8}$ respondents spread in North Sumatera Province. Analyzer used with Structural Equation Modeling approach with SMART-PLS software. The results show the influence of the social environment and the legal environment on the welfare of society with economic spending as mediators.
\end{abstract}

Keywords - social environment, legal environment, community welfare, economic expenditure

\section{INTRODUCTION}

Every year local governments create expenditure budget and revenues budget of local government in Indonesia called APBD. Local government expenditure or financial decisions are grouped into two, namely direct expenditure and indirect spending. Direct expenditure is usually used for infrastructure expenditure, economic expenditure and social expenditure. While indirect expenditure is often referred to as routine expenditure, this expenditure is used for wages expenditure and expenditure which are not related to infrastructure expenditure, economic expenditure and social spending

The composition of expenditure set by the local government can be an indicator of budget quality. The poor budget quality will be occurred if the budget made is not aligned to the public needs. The basic principles that must be accommodated in the budget is transparency, participatory, disciplinary, fairness, efficiency and effectiveness, as well as rational and measurable [1]

In improving the service and welfare of the community, local governments should have a betterfinancial management quality, especially to improve the quality of budgets. The local goverment budget is needed to determine the community needs. Community needs in the local budget was shown through the local government expenditure. Because of the funding capability limitation, local governments should manage expenditure efficiently and effectively [10], [12], [13] $\&$ [15]. Qualified budget is a budget that has structure and allocations shownin society needs [2]. [3] said that the fiscal sustainability had shown less guarantee. This is caused by the system that was adopted in a single budget year and zero-based budgeting, lack of transparency, lack of efficiency levels, and lack of accountability [17], [18] \& [19] . Secondly, in line with the development of modern financial management system, Indonesia need to reform it's budgetting system, Indonesia must adopt the principles of public finance management which is used internationally.

Financial decisions made by local governments affect the welfare of the people. Local governments need to consider the focus of their financial decisions. According to the International City / County Management Association (ICMA) there are several factors that influence the local government's financial decisions. They are: (1) Political Environment/citizen involvement, (2) economic environment, (3) Social environment, and (4) Legal environment [4].

The indicator of political environment (citizen involvement) are citizen surveys, neighborhood forums, town hall meetings and Interactive websites. Results of Citizen Survey often are used by communities as part of goal setting and strategic or comprehensive planning. By understanding 
what residents think are the characteristics of the community that are most important to protect or improve, by knowing what is working and what remain challenges, local leaders can be guided toward planning for a community that builds on its strengths and improves in the areas that matter the most [5].

The existence of neighborhood- based governance entities created by community-building initiatives are accepted by local government. Representatives of local government neither see them as a fundamental intrusion on the roles, responsibilities, or prerogatives of elected government, nor as much of a threat to its representative and provisionary functions. Because such entities were seen as grounded in their neighborhood, public officials therefore assumed them to be able to act more effectively as a conduit of information, an organizer of interests, and a broker among neighborhood actors and between them and the city. Indeed, neighborhood-based governance entities, whether structured to guide the planning and implementation of particular, time-limited initiatives or housed in more enduring structures, were seen as potentially important mechanisms for fostering the kind of sought-after "partnership" between local government and its neighborhoods that many officials described as desirable [20], [21]. However, public officials identified some basic limitations of neighborhood- based governance entities: they should inform but not make city policy; they lack mechanisms of accountability; they cannot balance needs across constituencies city-wide; and they cannot assume the statutory responsibilities for particular protective and provisionary functions that lie with the city and state. Public officials and neighborhood- based governance bodies should explore the degree to which such entities are sufficiently representative of neighborhood interests, and about the grounds on which they could make such a claim. These concerns, however, did not fundamentally challenge the legitimacy of using neighborhood-based governance structures as a mechanism to foster community change, as long as they remained within the bounds of the roles that were deemed appropriate for them to engage in. Similarly, concerns about the long-term viability of such endeavors had more to do with the question of technical capacity and sustaining financial support than with the issues of political control or representational legitimacy [6] \& [22].

The welfare of the community in an area is affected by the financial decisions made by the local government concerned. As described early, local and central government financial decisions are strongly influenced by (1) the Political Environment, (2) the economic environment, (3) the Social environment, and (4) the legal environment. According Tripriyono, political environment and economic environment have a significant effect on community welfare [7]. Based on the previous explanation, the authors see the importance of doing research and analysis deeper to find empirical evidence of influence ofsocial environment and legal environmrnt on financial decisions and their impact on community welfare In North Sumatra Province. The model developed from the theories was :
Figure 1. Research Model

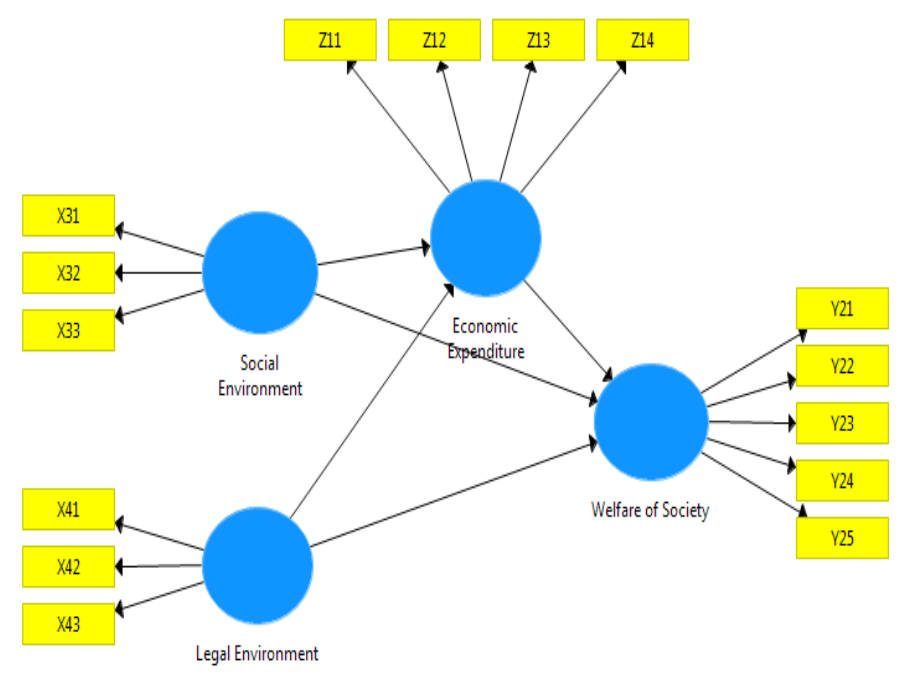

\section{METHOD}

Primary data is used in this study. The hypothesis was tested by Structural Equation Modeling (SEM) with the aid of SMART PLS software. The data analysis technique in this research employed Structural Equation Modeling (SEM). SEM is a set of statistical techniques allowing testing of a series of relationships simultaneously. Dependent variable in this study was community welfare, economic expenditure as intervening variable and independent variables were social environment and legal environment.

The hypotheses were tested using Structural Equation Modeling (SEM) with AMOS software tools. The equation is formed as follows:

$$
\begin{aligned}
& \mathrm{Y}=\alpha+\mathrm{b} 1 \mathrm{X} 1+\mathrm{b} 2 \mathrm{X} 2+\mathrm{e} \ldots \ldots \ldots \\
& \mathrm{Z}=\alpha+\mathrm{b} 1 \mathrm{X} 1+\mathrm{b} 2 \mathrm{X} 2+\mathrm{b} 3 \mathrm{Y}+\mathrm{e}
\end{aligned}
$$

Where:
$\mathrm{Y}$

$\mathrm{X} 1$

$\mathrm{X} 2$

Z

b1, b2, b3

$\alpha$

e
$=$ Community welfare

$=$ Social Environment

$=$ Legal Environment

$=$ Economic Expenditure

$=$ Coefficient

$=$ Constant

$=$ Error 


\section{RESULT}

\section{A. Measurement Model}

The measurement model links between latent variables with manifest variables as follows:

Figure2. Standardization Coefficient

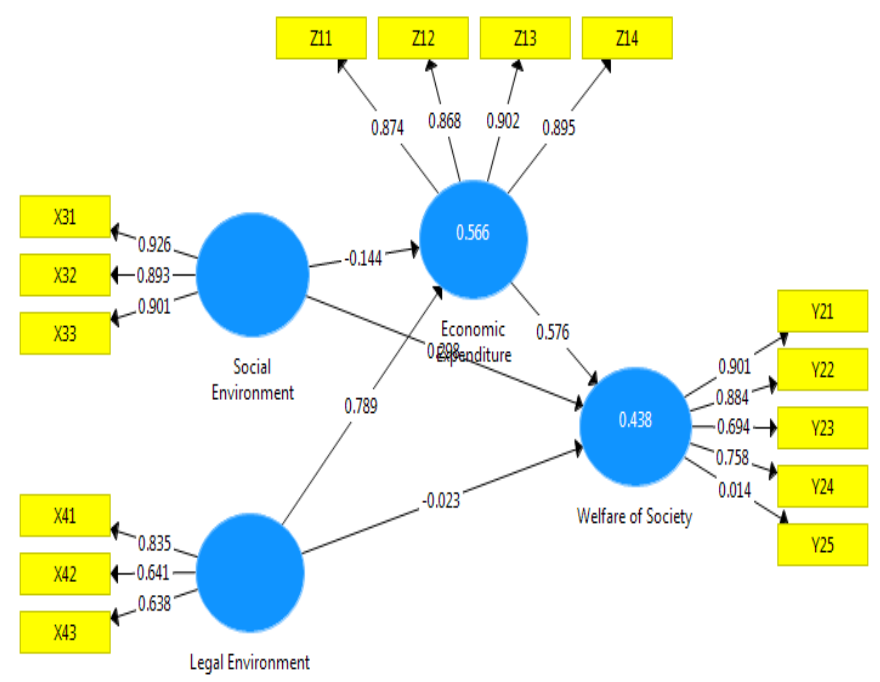

\section{B. Structural Model}

\section{1) Total effect}

Inner model evaluation through the bootsraping menu also generates $\mathrm{T}$-statistics values that will be used to test the hypothesis. The criterion is T-statistic $>1.96$. The result of $\mathrm{T}$ statistics value in the table path coefficients is presented in the following Table:

Table 1. Path Coefficients

\begin{tabular}{|l|c|c|c|c|}
\hline & $\begin{array}{c}\text { Social } \\
\text { Environmen } \\
\mathrm{t}\left(\mathrm{X}_{1}\right)\end{array}$ & $\begin{array}{c}\text { Legal } \\
\text { Environme } \\
\left.\mathrm{nt}\left(\mathrm{X}_{2}\right)\right)\end{array}$ & $\begin{array}{c}\text { Economic } \\
\text { Expenditure } \\
(\mathrm{Z})\end{array}$ & $\begin{array}{c}\text { Community } \\
\text { Welfare } \\
\text { /Welfare of } \\
\text { Society (Y) }\end{array}$ \\
\hline $\begin{array}{l}\text { Social } \\
\text { Environment } \\
\left(\mathrm{X}_{1}\right)\end{array}$ & & & -0.144 & 0.215 \\
\hline $\begin{array}{l}\text { Legal } \\
\text { Environment } \\
\left.\mathrm{X}_{2}\right)\end{array}$ & & & 0.789 & 0.431 \\
\hline $\begin{array}{l}\text { Economic } \\
\text { Expenditure } \\
(\mathrm{Z})\end{array}$ & & & & \\
\hline $\begin{array}{l}\text { Community } \\
\text { Welfare } \\
\text { /Welfare of } \\
\text { Society (Y) }\end{array}$ & & & & 0.576 \\
\hline Sources PLS Output, & & & \\
\hline
\end{tabular}

Sources : PLS Output, (2017).

\section{2) Indirect Effect}

Tests of indirect effects on hypotheses can be seen in the following indirect effect test Table:
Table 2. The result of Indirect Effect

\begin{tabular}{|l|c|c|c|c|}
\hline & $\begin{array}{c}\text { Social } \\
\text { Environmen } \\
\mathrm{t}\left(\mathrm{X}_{1}\right)\end{array}$ & $\begin{array}{c}\text { Legal } \\
\text { Environme } \\
\left.\mathrm{nt}\left(\mathrm{X}_{2}\right)\right)\end{array}$ & $\begin{array}{c}\text { Economic } \\
\text { Expenditure } \\
(\mathrm{Z})\end{array}$ & $\begin{array}{c}\text { Community } \\
\text { Welfare } \\
\text { /Welfare of } \\
\text { Society (Y) }\end{array}$ \\
\hline $\begin{array}{l}\text { Social } \\
\text { Environment } \\
\left(\mathrm{X}_{1}\right)\end{array}$ & & & & 0.215 \\
\hline $\begin{array}{l}\text { Legal } \\
\text { Environment } \\
\left(\mathrm{X}_{2}\right)\end{array}$ & & & & 0.431 \\
\hline $\begin{array}{l}\text { Economic } \\
\text { Expenditure } \\
(\mathrm{Z})\end{array}$ & & & & \\
\hline $\begin{array}{l}\text { Community } \\
\text { Welfare } \\
\text { /Welfare of } \\
\text { Society (Y) }\end{array}$ & & & & 0.215 \\
\hline
\end{tabular}

Sources : PLS Output, (2017).

Based on the Table of indirect influence in the above Table shows that hypotheses are accepted because the statistical value of each hypothesis is greater than 1.96 so that the decision of hypothesis testing reject $\mathrm{H} 0$ and accept alternative hypothesis. In addition to hypothesis testing through the bootsrapping menu that produces T-statistics, inner model evaluation is also done by reviewing the value of $\mathrm{R}$-Square (coefficient of determination). The R-square value generated from the inner model evaluation is presented in the following Table:

Table 3. R-Square Value

\begin{tabular}{|c|c|c|}
\hline & R Square & R Square Adjusted \\
\hline Economic Expenditure (Z) & 0,566 & 0,562 \\
\hline Community Welfare (Y) & 0,438 & 0,430 \\
\hline
\end{tabular}

Sources : PLS Output, (2017).

\section{DISCUSSION}

Changes in social environment such as population, age distribution, and personal income have significant and lasting effects on local financial decision. As population increases and fixed costs are divided among more households, the resulting economies of scale will mean lower per-unit costs. Because financial obligations do not decline in proportion to population loss, communities with declining populations have difficulty reducing spending. Spending for public education, public safety, and recreational services are the budget categories most likely to be affected by the age distribution of the population. Research shows consistently that growth in personal income significantly affects the size of local government financial decision. Higher income households often demand more and better services from government, although these same households are more likely to advocate limited government, especially at the state and federal levels.

This research found that legal environment have negative effect on community welfare. This finding show that to increasing community welfare, local government can't use balance budget. Otherwise enhance community welfare local government should focus on social and economic expenditure.

Change in Legal environment factors effect on financial decision of local government three principal ways, they are budgetary balance, mandates and a combines effect. The legal environment in which state and local government financial 
decision operates typically requires budgetary balance that is, current revenues must equal current expenditures. Requirements for budgetary balance are complicated by a technical question: Is the budget balanced on a cash basis (i.e.; revenues are recorded when cash is received, and expenditures recorded when disbursed) or on a modified accrual basis (i.e., liabilities are recognized at the time they are incurred, and revenues are recognized when they are available for budgeted purposes)?. This question is important because cash balances can be easily manipulated: to make the budget look more balanced than it is, payments can be delayed until the following fiscal year and revenue collections can be accelerated for credit to the current year.

A mandate involves one level of government requiring another level to provide particular services or follow certain procedures, as well as specifying the quality or frequency of service provision. Both the federal and state government imposes mandates on local governments. The problem is Unless the federal or state government also provides full funding to implement the mandates, local officials may have to cut other services to comply. Communities suffering the effects of recessions have sometimes been hit simultaneously by unfunded mandates and cutbacks in state spending.

Forbidding particular revenue sources, constraining tax increases, requiring balance, and mandating some services and service levels, are a combination of factors that has created enormous fiscal stress at the local level during the past three decades.

In fact, manager of local government see a beneffit in working with and through identifiable organizations and community leaders who can broker relationships and provide apparent legitimacy to government activities in the neighborhood. However, public officials did identify a number of limitations of such entities - that they should inform but not make policy, that they cannot balance needs across constituencies city wide, that they lack accountability mechanisms, and that they cannot assume responsibilities that are assigned by statute to government [8] Finally, financial decision of local government effect on community welfare. The higher quality the higher community welfare.

\section{CONCLUSION}

Social environment have positive and significant effect on local government financial decision but legal environment have negative and significant effect on local government financial decision.

Local government financial decision have significant effect on community welfare. The effect of social environment and legal environment to community welfare mediated by financial decision of local government.

\section{REFERENCES}

[1] Badaruddin. 2006. Utilization of Capital in Efforts to Increase Family Welfare and Communities (Study on Rubber Farmers Community in Rao Sub-district, Pasaman District, West Sumatera). Wahana Journal. Vol. 12 No. 2. [downloaded November 9, 2014]. Can be downloaded at http://jurnal.unej.ac.id/index.php/JSEP/article/viewFile/800/616
[2] Erlina. 2017, Conflict of Interest Impact: Factors Analysis Affecting the Budget Quality in Medan City. International Journal of Economic Research.Vol.14, 135-145

[3] Peacock, Alan T., and Jack Wiseman. Peacock and Wiseman on Growth of Public Expenditure, Public Choice, vol.78 (2) 1994

[4] ICMA,.2016. 4 Factors influencing Local Government Financial Decisions. ICMA Research.

[5] ICMA,.2016. 4 Factors influencing Local Government Financial Decisions. ICMA Research.

[6] Chaskin, J. Robert \& Ali Abudimah, A View From The City: Local Government Perspectives On Neighborhood-Based Governance In Community-Building Initiatives

[7] Erlina. 2017, Conflict of Interest Impact: Factors Analysis Affecting the Budget Quality in Medan City. International Journal of Economic Research.Vol.14, 135-145

[8] Burhan, Junaidy, Sirojuzilam, Erlina, Nes Yandri Kahar. 2015. Regional planning and development of kota Medan: Effect on electrical power distribution (case study on Medan city development area). International Journal of Applied Engineering Research. 10(17). 3828638290 .

[9] Rurhan Iunaidy Frlina Sirojuzilam, Nes Yandri Kahar, R. T. Mohamad and A. A. Zulkefle. 2015. An analysis of the effects of electrical energy distribution on the economic growth of kota Medan. International Journal of Applied Engineering Research. 10(17). 3827138273 .

[10] Dalimunthe, D.M.J.,Fadli, and Muda, I. 2016. The application of performance measurement system model using Malcolm Baldrige Model (MBM) to support Civil State Apparatus Law (ASN) number 5 of 2014 in Indonesia. International Journal of Applied Business and Economic Research. 14(11). 7397-7407.

[11] Gusnardi, Riadi, R.M., and Muda, I. 2016. Competency mapping and analysis of students competency based on economics subject national examination and its alternative solutions in state high schools at Pekanbaru. International Journal of Economic Research. 3(5). 21332148 .

[12] Lubis, A.,Torong, Z.B., and Muda, I. 2016. The urgency of implementing balanced scorecard system on local government in North Sumatra - Indonesia. International Journal of Applied Business and Economic Research. 14(11). 7575-7590.

[13] Lubis, A.F., Lubis, T.A., and Muda, I. 2016. The role of Enterprise Resource Plan (ERP) configuration to the timeliness of the financial statement presentation. International Journal of Applied Business and Economic Research. 14(11). pp,7591-7608.

[14] Lutfi, M.,Nazwar, C., and Muda, I 2016. Effects of investment opportunity set, company size and real activity manipulation of issuers in Indonesia Stock Exchange on stock price in Indonesia. International Journal of Economic Research. 13(5). 2149-2161.

[15] Muda, I and Abykusno Dharsuky. 2015. Impact Of Region Financial Information System (SIKD) Quality, Role Ambiguity And Training on Precision of Financial Statement of Local Government Presentation In North Sumatra. International Journal of Applied Business and Economic Research, 13(6). 4283-4304.

[16] Muda, I, Deni Yuwilia Wardani, Erlina, Azhar Maksum, Ade Fatma Lubis and Rina Bukit. 2017. The Influence of Human Resources Competency and The Use of Information Technology on The Quality of Local Government Financial Report with Regional Accounting System as an Intervening. Journal of Theoretical and Applied Information Technology. 95(17). 1432-1451.

[17] Muda, I, Dharsuky. A., Siregar, H.S., and Sadalia, I. 2017. combined loading and Cross-dimensional loadings timeliness of presentation of financial statements of local government. IOP Conference Series : Materials Science and Engineering. 180. doi: 10.1088/1757899X/180/1/012099.

[18] Muda, I, Marlon Sihombing, Erni Jumilawati and Abikusno Dharsuky. 2016. Critical Success Factors Downstream Palm Oil Based Small And Medium Enterprises (SME) In Indonesia. International Journal of Economic Research. 13(8). 3531-3538.

[19] Muda, I, Mutia Ismail and Marhayanie. 2017. Impact Allocation Capital Expenditure on The Improvement of the Local Government Assets in 
North Sumatra and Effect on Local Revenue Sustainability. International Journal of Economic Perspectives. 11(2). 151-164.

[20] Muda, I.,Dharsuky, A.,Sadalia, I., and Siregar, H.S. 2016. Impact of capital investments and cash dividend policy on Regional Development Bank (BPD) PT. Bank Sumut to the district own source revenue and economic growth. International Journal of Applied Business and Economic Research. 14(11). 7863-7880.
[21] Muda, Iskandar, 2017. The Effect of Supervisory Board CrossMembership and Supervisory Board Members' Expertise to The Disclosure of Supervisory Board's Report : Empirical Evidence From Indonesia. European Research Studies Journal. XX(3A). 702-716.

[22] Yahya, I, Torong, Z.B., and Muda, I. 2017. Influence Behavior in Legislature Budget Development of Regions in the Province of Aceh and North Sumatra. International Journal of Economic Research. 14(8). 147-159. 